\title{
Stone in ureterocele peeping through ureteric orifice
}

\author{
Jai Prakash, Apul Goel, Manoj Kumar, Satyanarayan Sankhwar
}

Department of Urology, King George Medical University, Lucknow, Uttar Pradesh, India

\section{Correspondence to}

Professor Apul Goel, drapul.goel@gmail.com
To cite: Prakash J, Goel A Kumar $\mathrm{M}$, et al. BMJ Case Rep Published online:

[please include Day Month Year] doi:10.1136/bcr-2013200168

\section{DESCRIPTION}

A 42-year-old man presented with a 2-day history of severe colicky pain in the left flank with vomiting. X-ray (figure 1A) and ultrasonography showed a $13 \mathrm{~mm}$ left vesicoureteric junction calculus (figure 1B) with moderate hydroureteronephrosis and small-sized right kidney. Serum creatine was $3.0 \mathrm{mg} / \mathrm{dL}$. In view of deranged renal function left side JJ stenting was planned. Cystoscopy showed large stone in ureterocele peeping through left ureteric orifice (figure 2A). The stone was nudged with ureteric catheter down into the bladder (figure 2B,C) and removed after cystolitholapaxy.

The incidence of ureterocele at autopsy is 1/500$1 / 4000 .{ }^{1}$ Ureterocele is a dilation of the submucosal ureter due to a delay in Chawall's membrane absorption. ${ }^{2}$ Ureteral atony and stagnation of urine in the ureterocele can precipitate stone formation. ${ }^{34}$ The prevalence of stone in a single ureterocele is variable (ranging between $4 \%$ and 39\%) depending on the geographical origin of the patient. ${ }^{5}$

A long-standing stone in ureterocele may be silent. Mandal et $a l^{6}$ showed that long-standing stone in ureterocele can cause ischaemia of the ureterocele wall, pressure necrosis and erosion. Spontaneous expulsion from ureteral orifice is rare as the orifice is small in ureterocele. In the present case, the patient suddenly became symptomatic because the stone in ureterocele protruded through the ureteric orifice and occluded the lumen completely by surrounding oedema. It is also possible that the stone eroded through the orifice. The opposite kidney was already compromised so the patient developed acute renal failure.
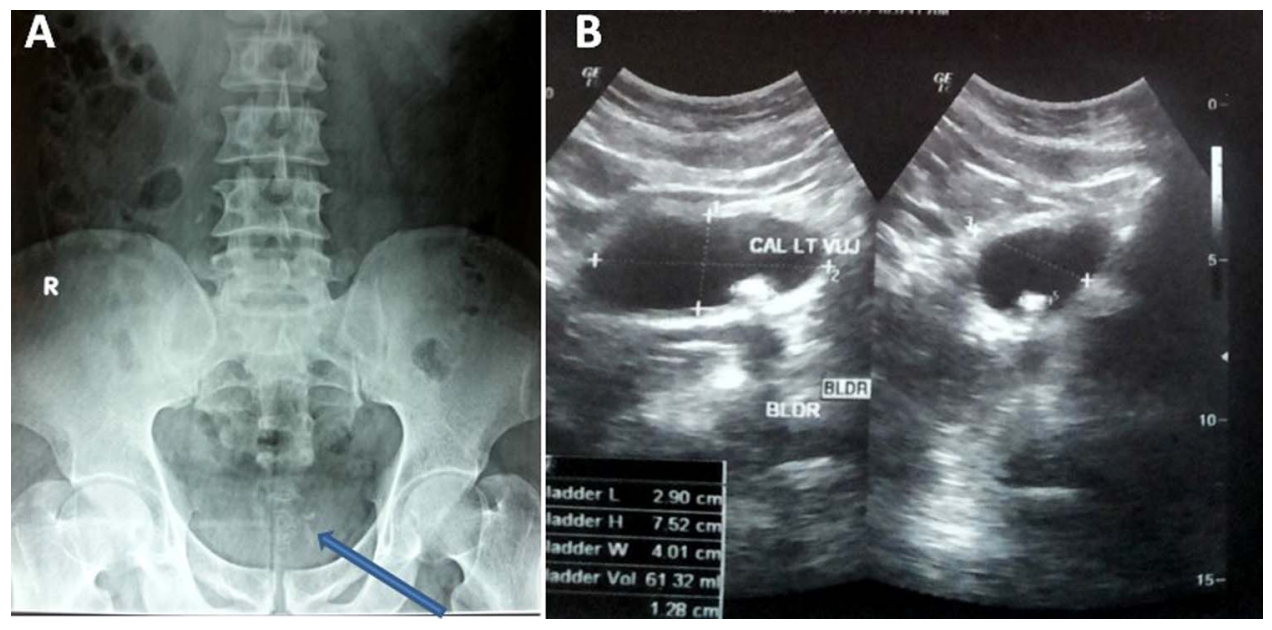

Figure 1 (A) X-ray showing left lower ureteric calculus. (B) Ultrasound showing left vesicoureteric junction calculus.
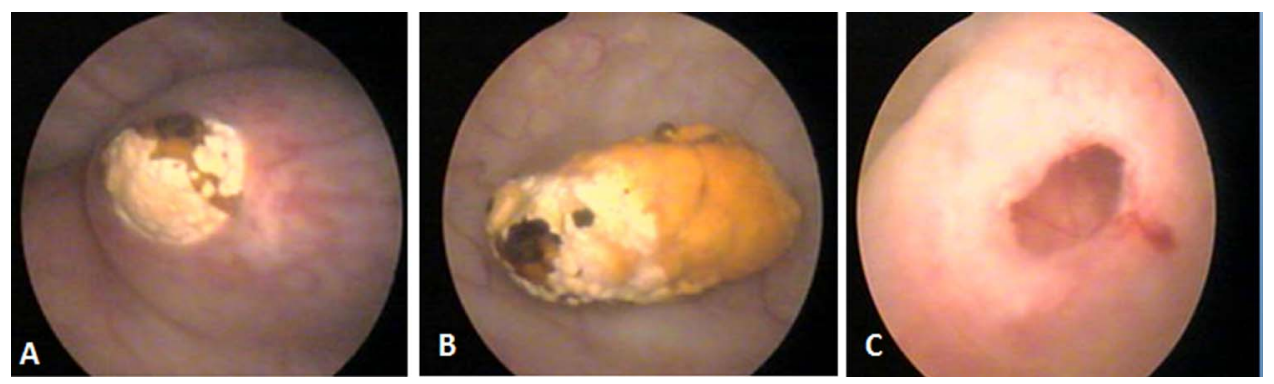

Figure 2 (A) Cystoscopy showing ureterocele with stone peeping through left ureteric orifice and surrounding oedema. (B) Stone nudged inside the urinary bladder. (C) Wide-mouthed orifice with ureterocele seen after the stone was manipulated into the bladder. 


\section{Learning points}

- Stone in ureterocoele can be silent or symptomatic.

- Long-standing stone in ureterocoele may protrude through the ureteric orifice and become suddenly symptomatic due to surrounding oedema and complete occlusion of lumen.

- If the opposite kidney is compromised it can lead to acute renal failure.

\section{Competing interests None.}

Patient consent Obtained.

Provenance and peer review Not commissioned; externally peer reviewed.

\section{REFERENCES}

1 Campbell M. Ureterocele: a study of 94 instances in 80 infants and children. Surg Gynecol Obstet 1951;93:705.

2 Stephens FD, Smith ED, Hutson JM. Congenital anomalies of the kidney, urinary and genital tracts. Oxford: Isis Medical Media, 1996.

3 Singh I. Adult bilateral non-obstructing orthotopic ureteroceles with multiple calculi: endoscopic management with review of literature. Int Urol Nephrol 2007;39:71-4.

4 Schlussel RN, Retik AB. Ectopic ureter, ureterocele, and other anomalies of the ureter. In: Wein AJ, Kavousi LR, Novick AC, et al. eds. Campbell-Walsh Urology. 9th edn. Philadelphia: WB Saunders, 2007:3398.

5 Messing EM, Henry SC. Stones in orthotopic, non-obstructing ureteroceles. J Urol 1979;122:403-4.

6 Mandal S, Goel A, Kumar M, et al. Spontaneous erosion of ureterocele wall by stone: rare images. Urology 2012;80:e43-4.

Copyright 2013 BMJ Publishing Group. All rights reserved. For permission to reuse any of this content visit http://group.bmj.com/group/rights-licensing/permissions.

BMJ Case Report Fellows may re-use this article for personal use and teaching without any further permission.

Become a Fellow of BMJ Case Reports today and you can:

- Submit as many cases as you like

- Enjoy fast sympathetic peer review and rapid publication of accepted articles

- Access all the published articles

- Re-use any of the published material for personal use and teaching without further permission

For information on Institutional Fellowships contact consortiasales@bmjgroup.com

Visit casereports.bmj.com for more articles like this and to become a Fellow 